\title{
BIOGEOCHEMICAL PROCESSES AFFECTING GROUNDWATER DISCHARGE IN A CHLOROBENZENE- CONTAMINATED WETLAND
}

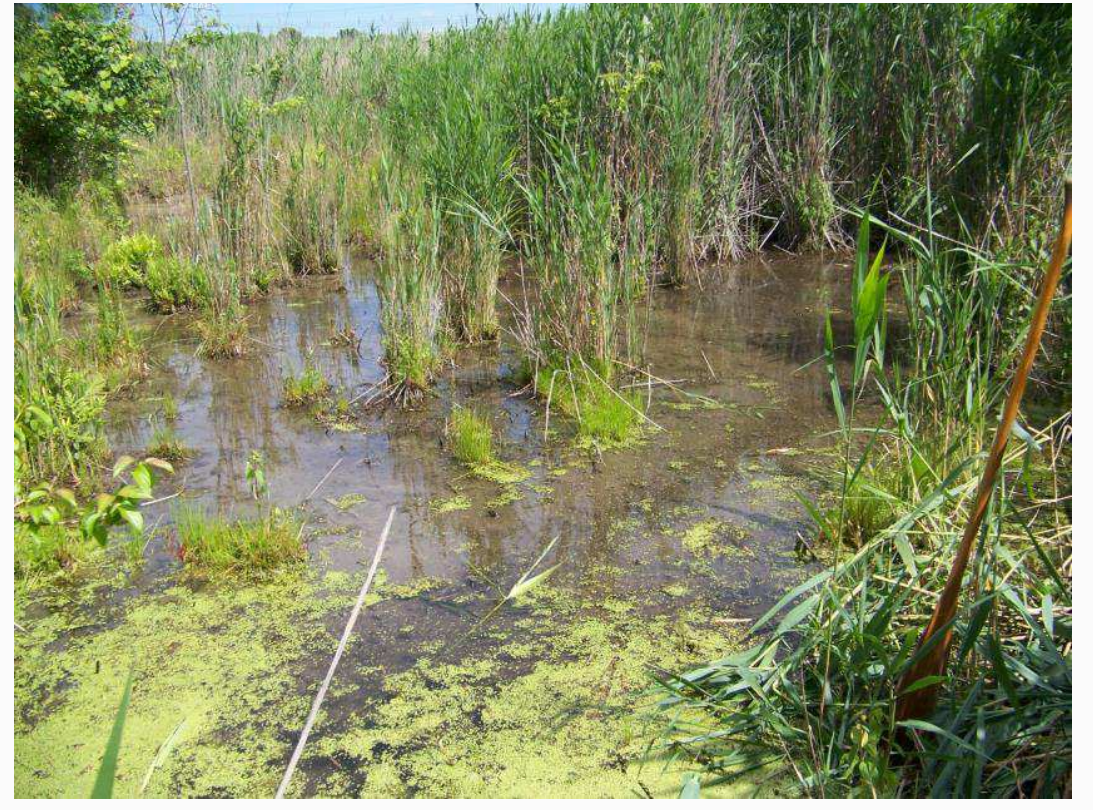

Michelle M. Lorah USGS, Baltimore, MD

Isabelle M. Cozzarelli, Denise Akob USGS, Reston, VA

\section{In cooperation with}

USEPA Region III 


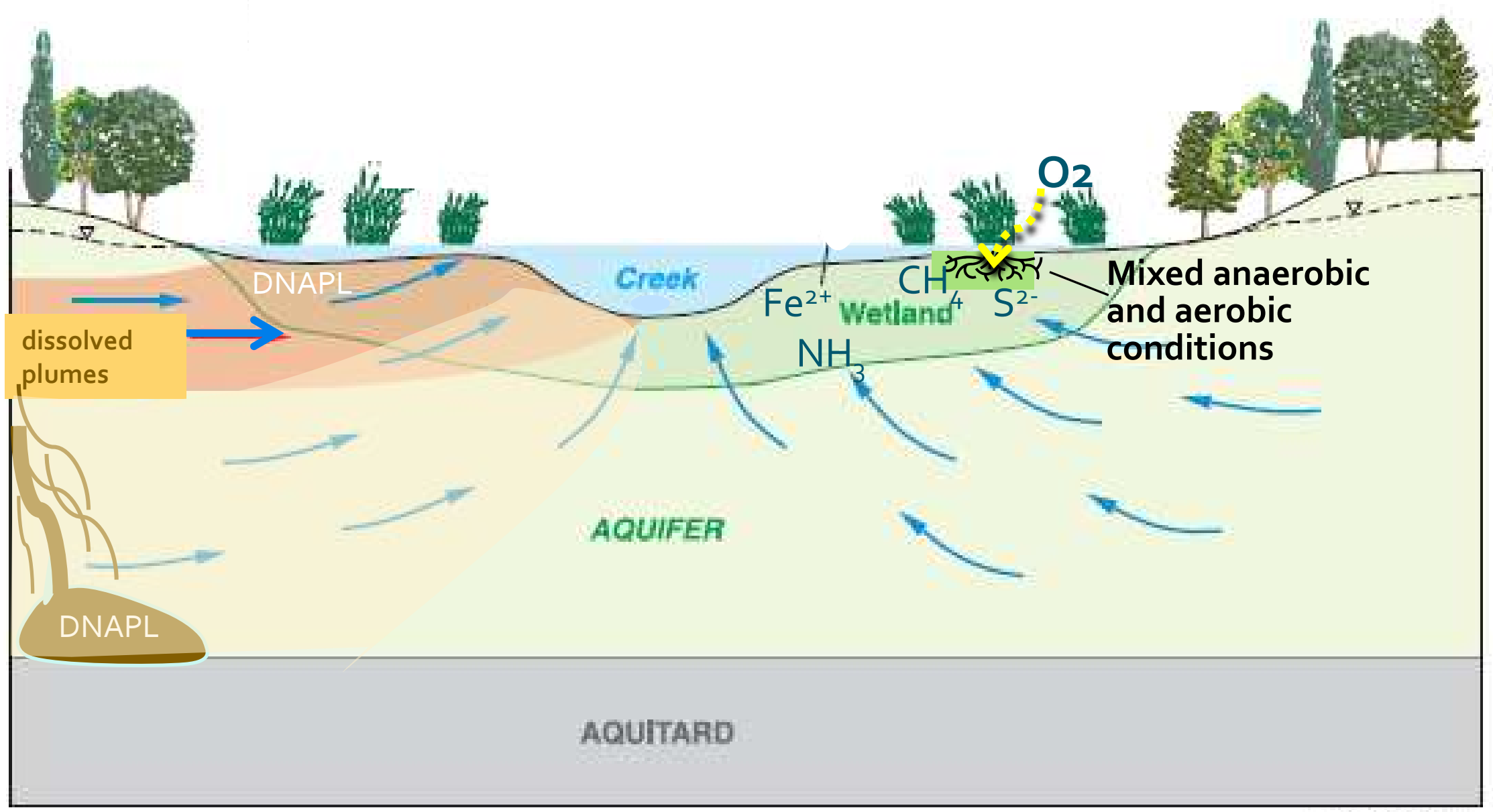

Conceptual model for contamination in wetland 


\section{Biodegradation Pathways}

Anaerobic (reductive dechlorination)

- CB serves as terminal electron acceptor

- Separate e- donor required

- rate decreases with decreasing number $\mathrm{Cl}$

Aerobic (oxidation)

- $\mathrm{O}_{2}$ required as electron acceptor

- CBs utilized as $C$ and $e^{-}$ donor

- rate increases with decreasing number $\mathrm{Cl}$

- Short-lived intermediates

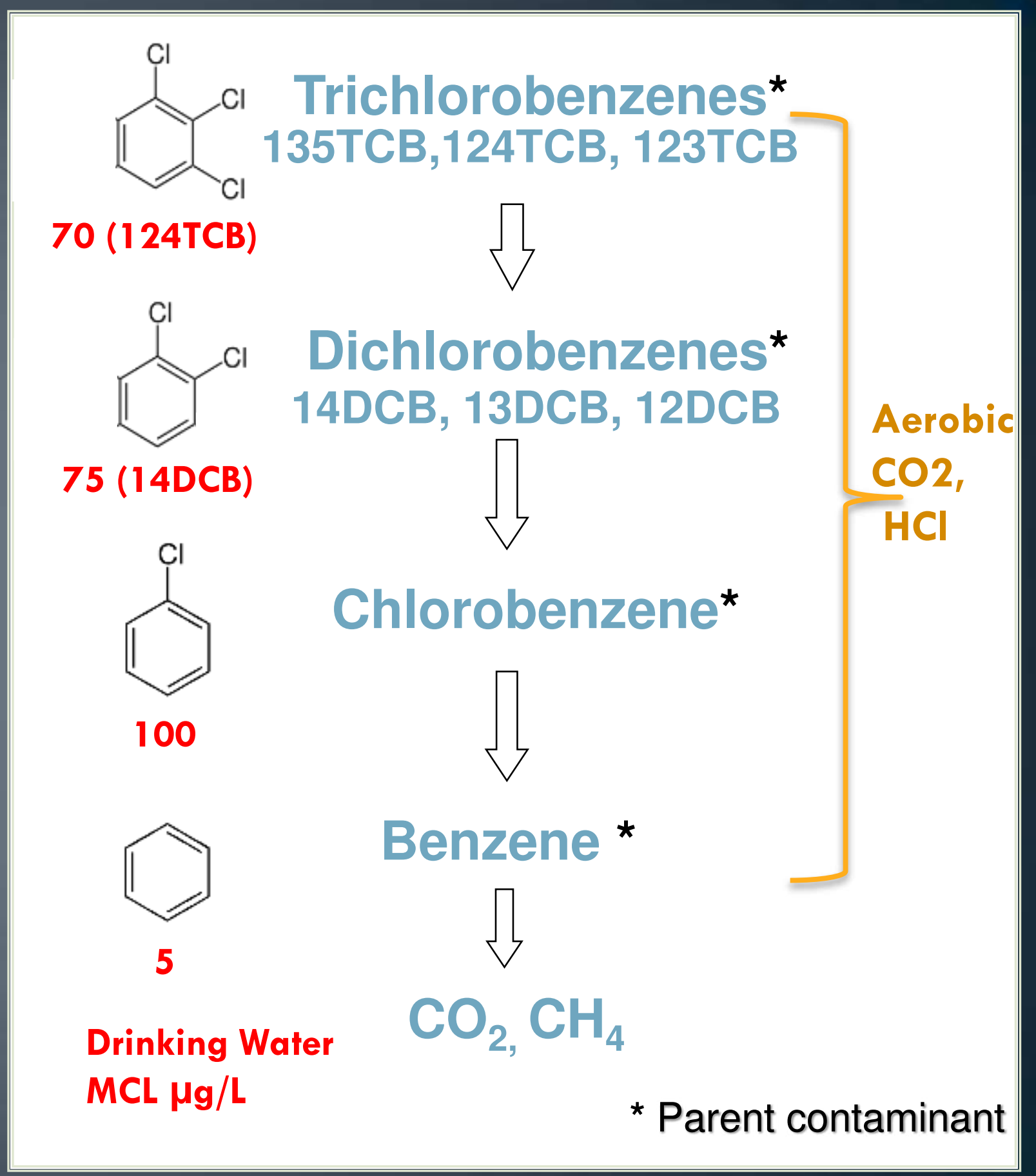


-Dec 20 I 0-Nov 20 I I

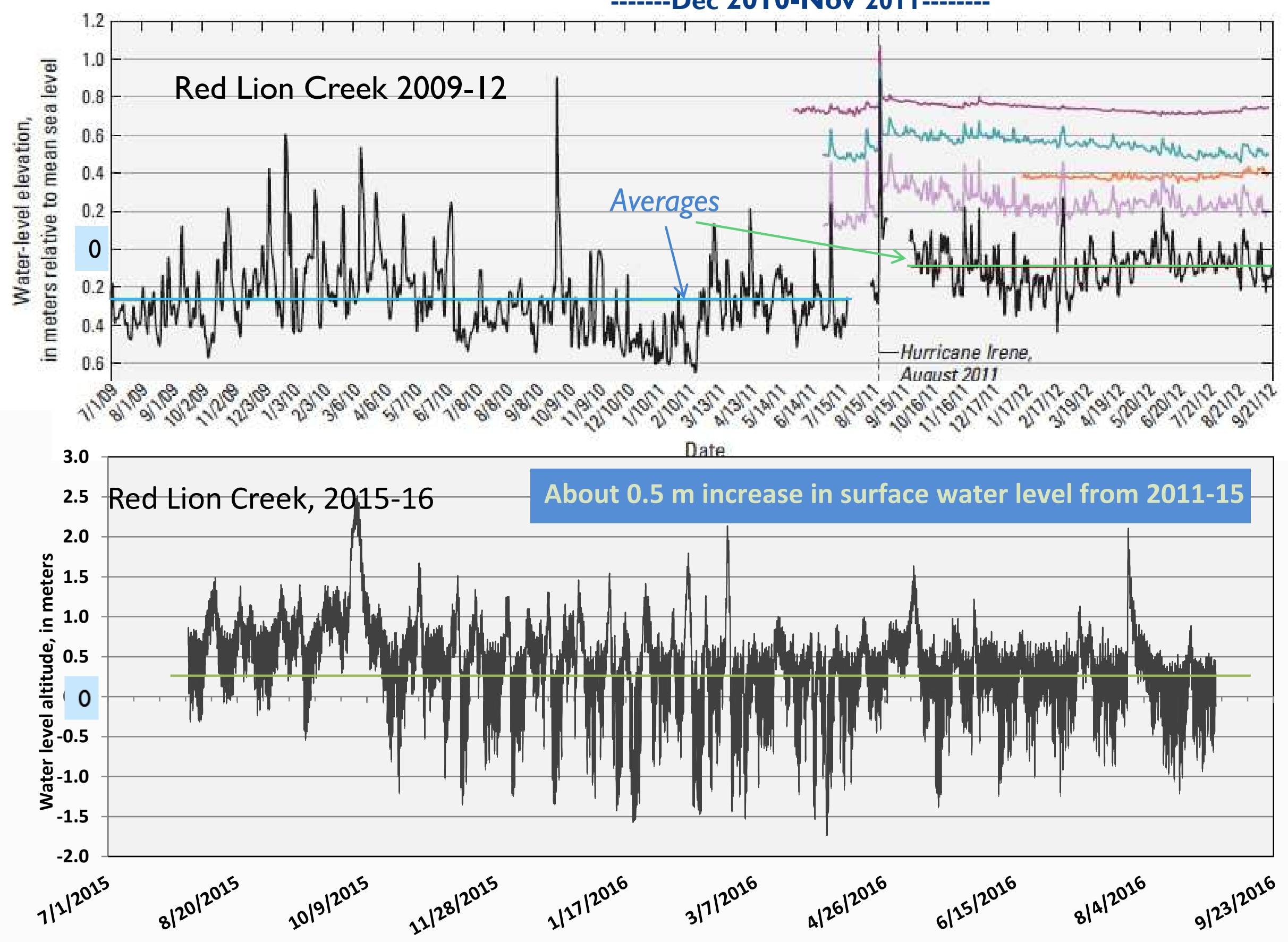




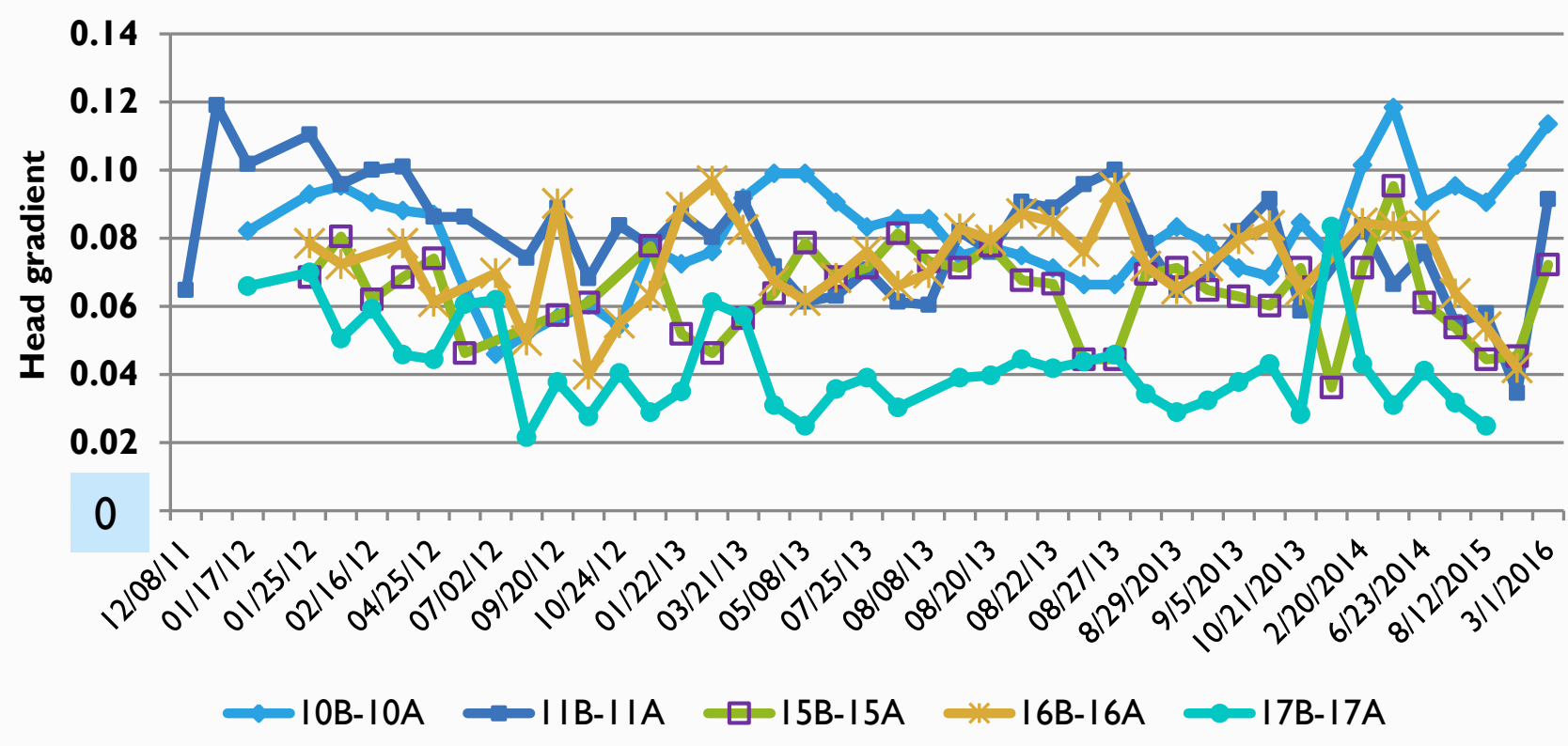

Vertical head gradients in wetland piezometers have remained upward $(>0)$ during 201 1-16, despite the rise in creek stage and tidal flooding of wetland...

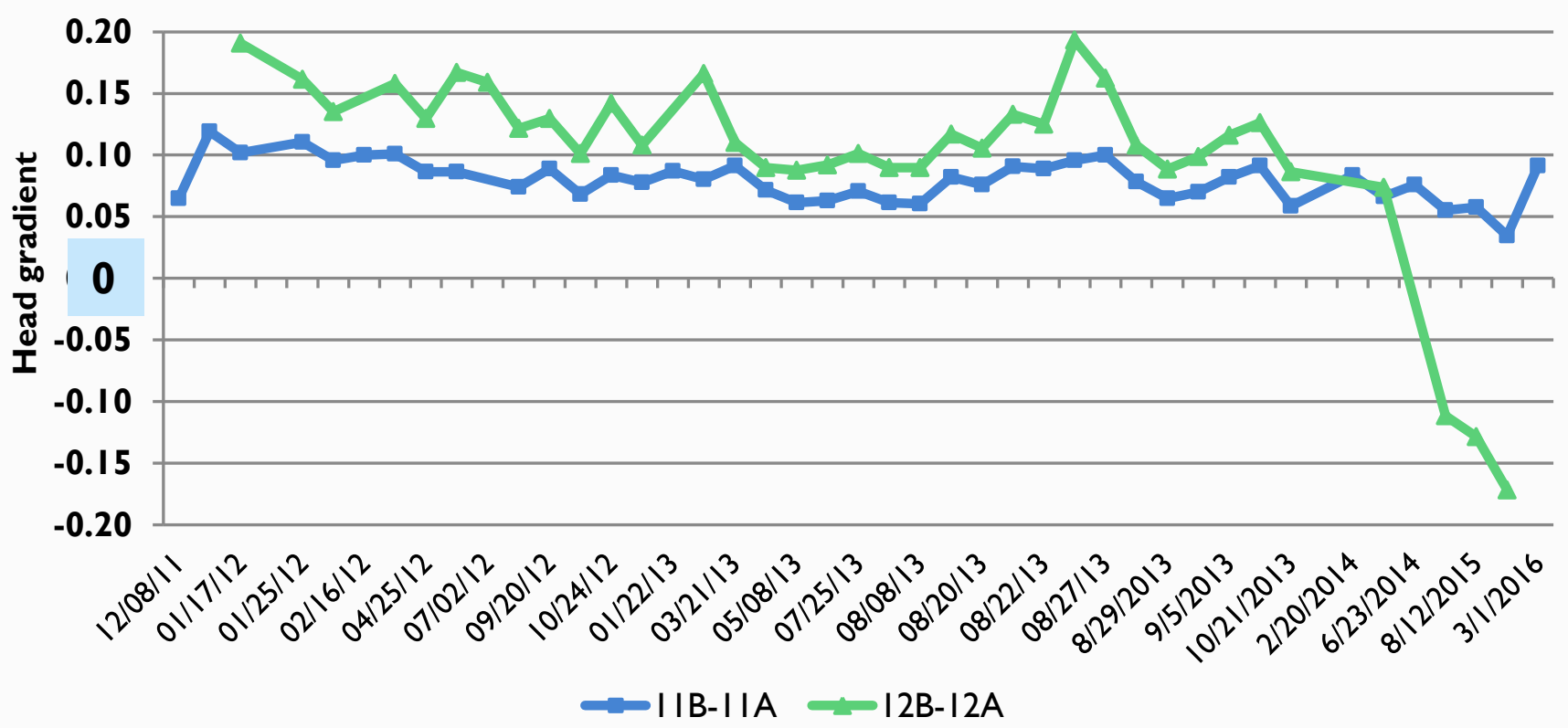

except site 12 , now located in creek channel, showed a reversal in gradient 3 years after the broken tide control gates. 


\section{Groundwater Sampling Sites, 20 I0-II and 20 I5-I6}

\section{EXPLANATION \\ SAMPLER TYPE AND IDENTIEIER}

143 Passive Diffusion Bag (PDB) sampler

Drive-point piezometer

- Drive-point piezometer and PDB

$\phi$ Drive-point piezometer and peeper

$39^{\circ} 36^{\prime} 20$

- Drive-point piezometer, peeper, and PDB

Drive-point piezometer and PDB (monthly sample)

典 Drive-point piezometer, peeper, and PDB (monthly sample)

-.m- Wetland dividing line for northwest and northeast wetland areas

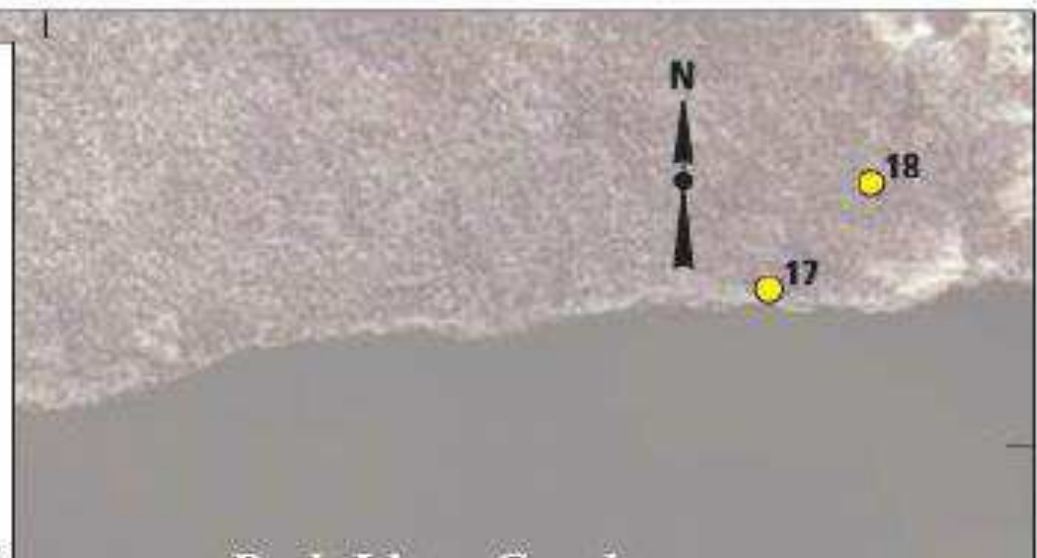

Rod Lion Crook
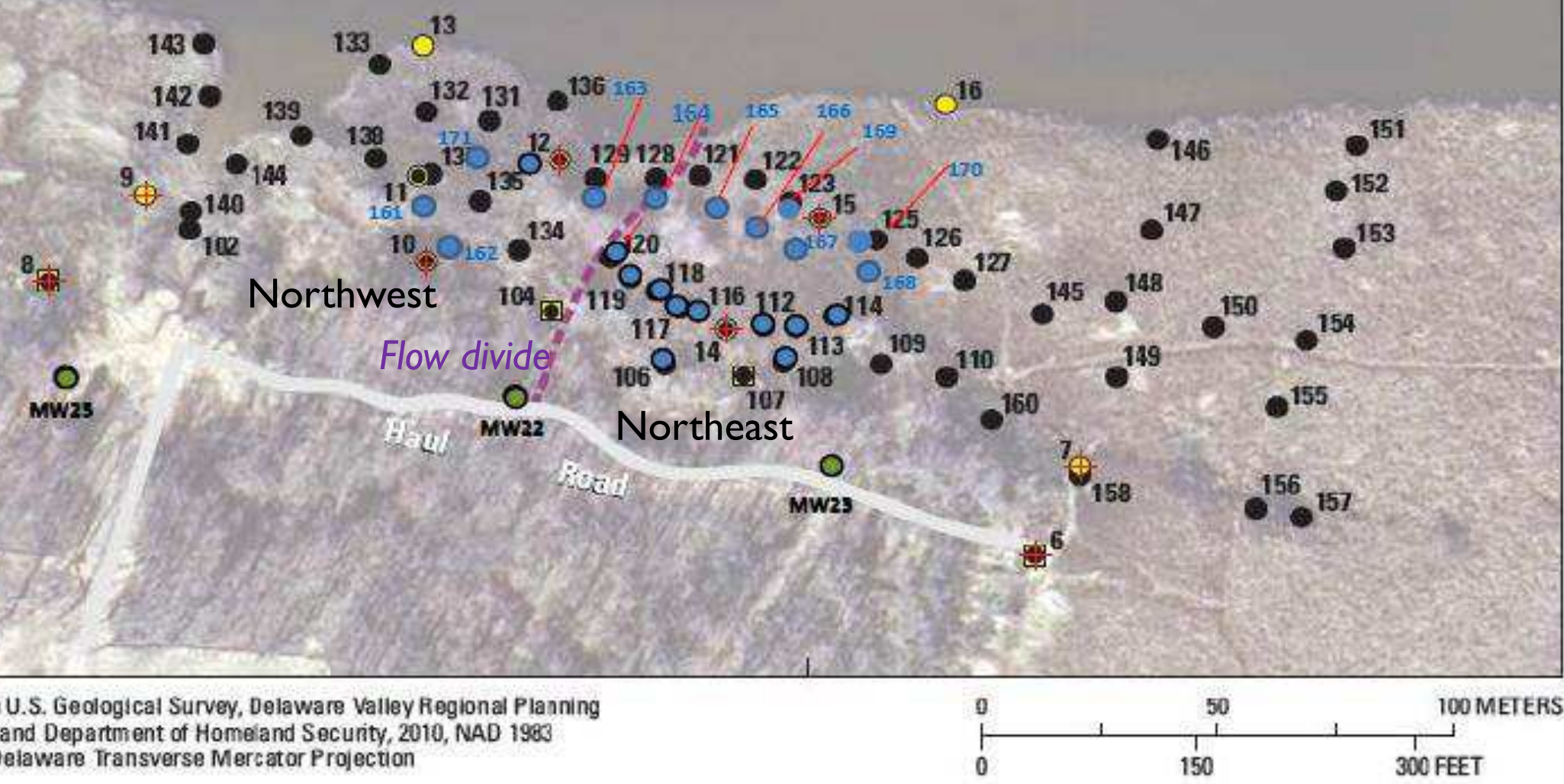


\section{Groundwater Sampling}

- Passive diffusion bags (PDBs) and dialysis samplers at about 45 sites

- 2 inch drivepoints at 13 sites (plus upland wells)

- 2-ft or 4-ft long porous membrane samplers (peepers) 

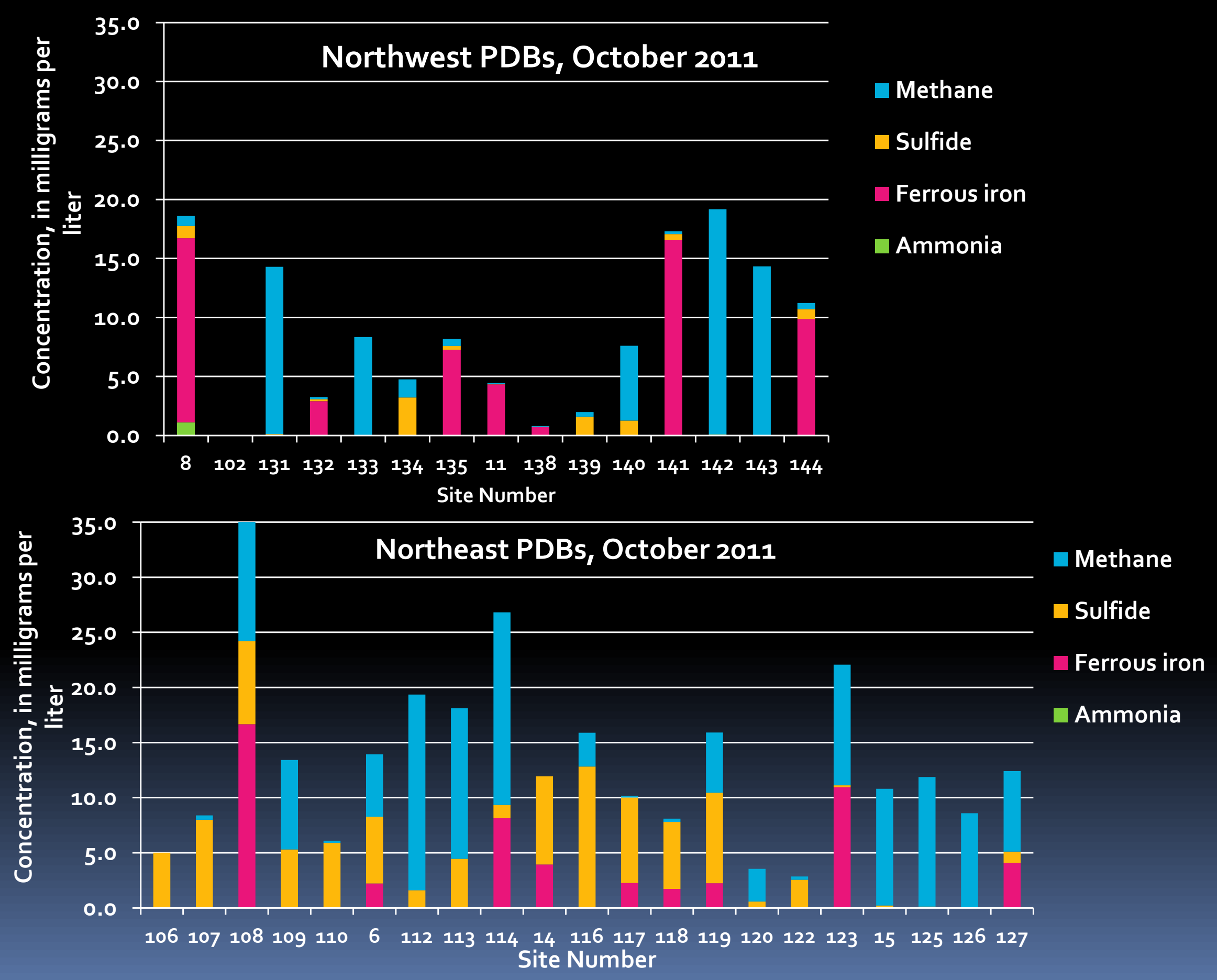


\section{PDBs, Shallow Wetland Groundwater (20- $30 \mathrm{~cm}$ depth)}
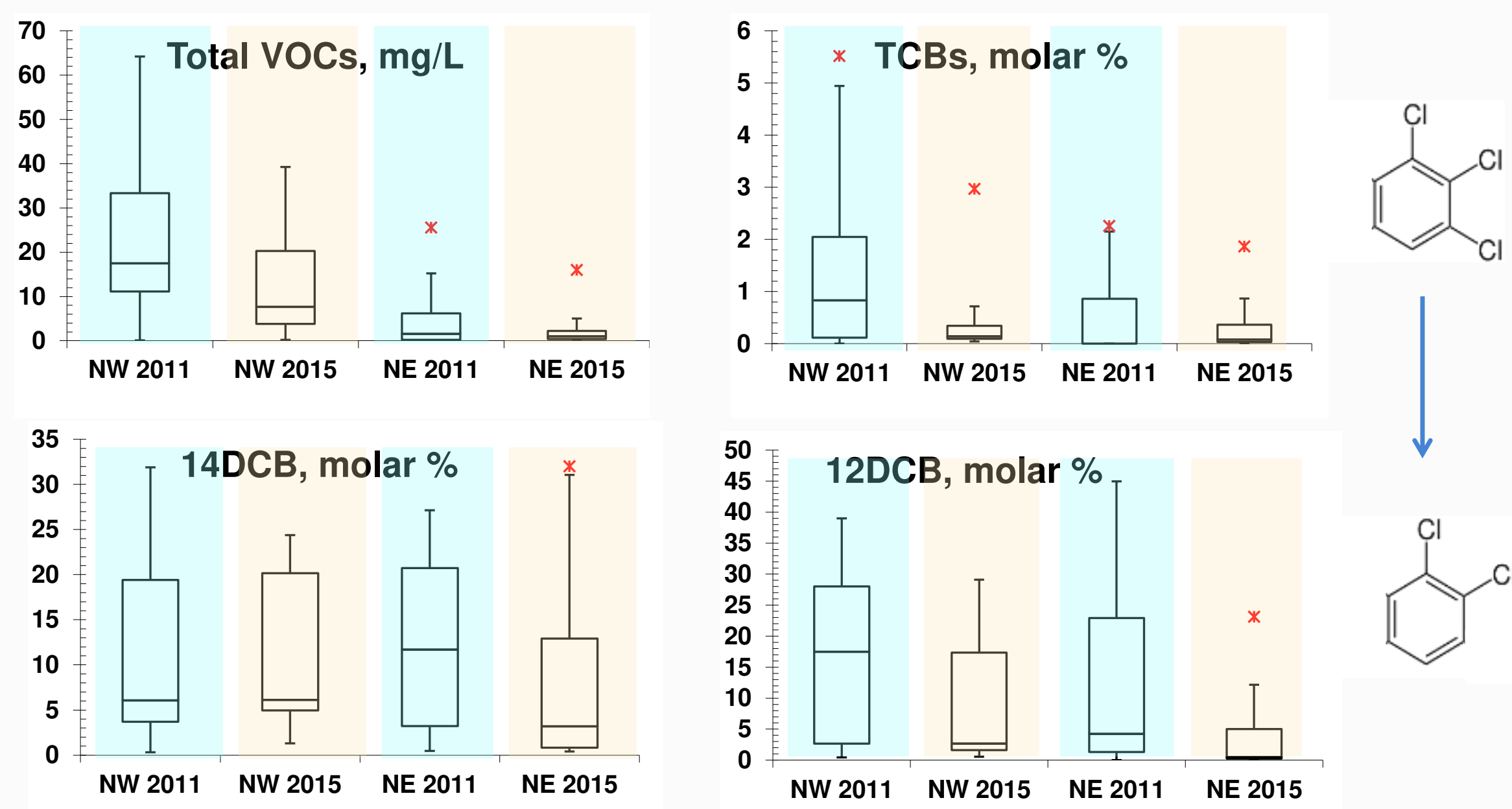

In 20I5, total VOC concentrations decreased, and VOC composition showed lower percent TCBs and DCBs. 


\section{PDBs, Shallow Wetland Groundwater (30- $45 \mathrm{~cm}$ depth)}

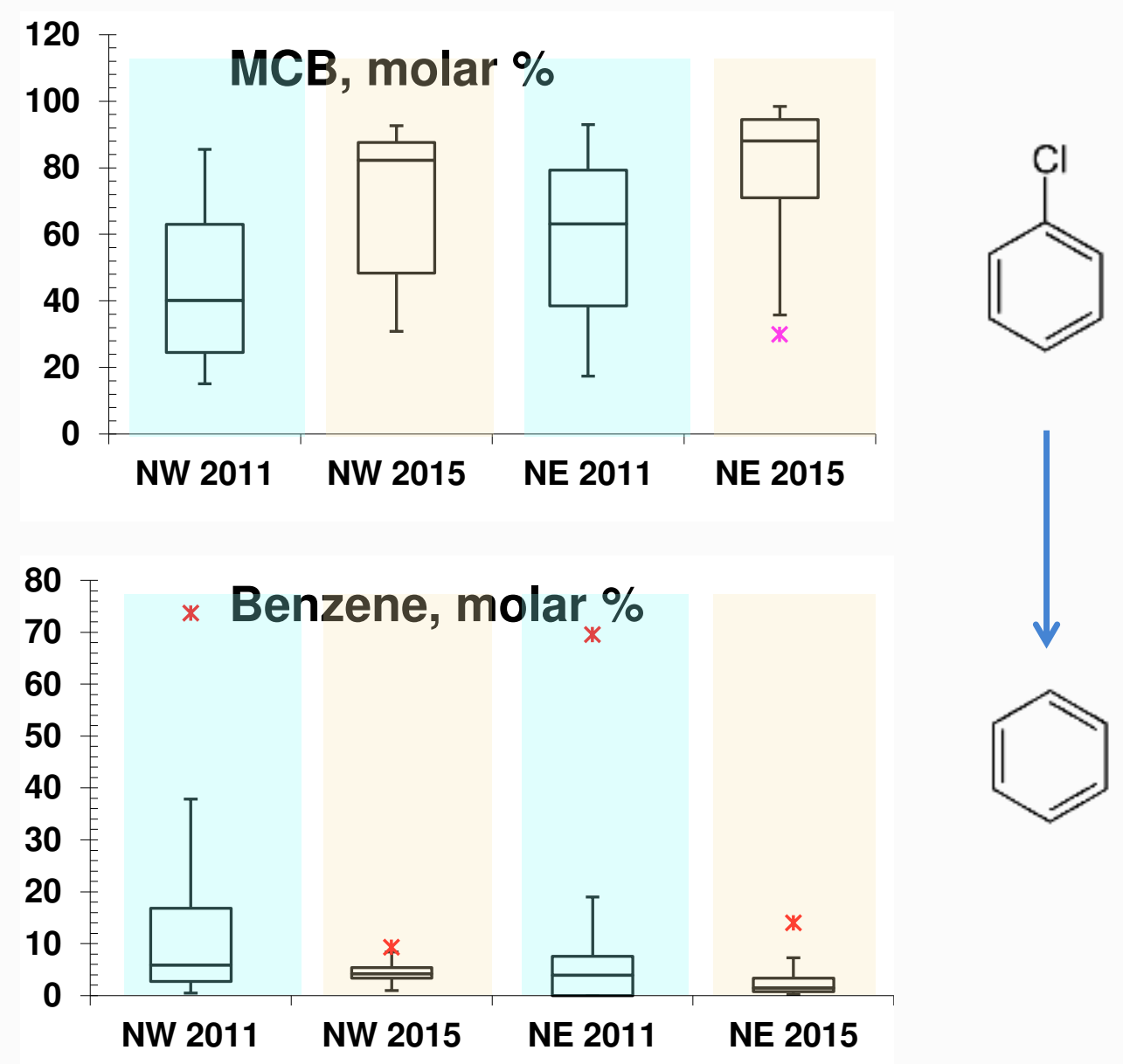

In $2015, \mathrm{VOC}$ composition showed higher percent $\mathrm{MCB}$ (median $>80$ percent), but equal or lower percent benzene compared to $20 \mathrm{II}$. 


\section{Chloride with Depth (Peepers)- effect of surface-water infiltration or ET?}
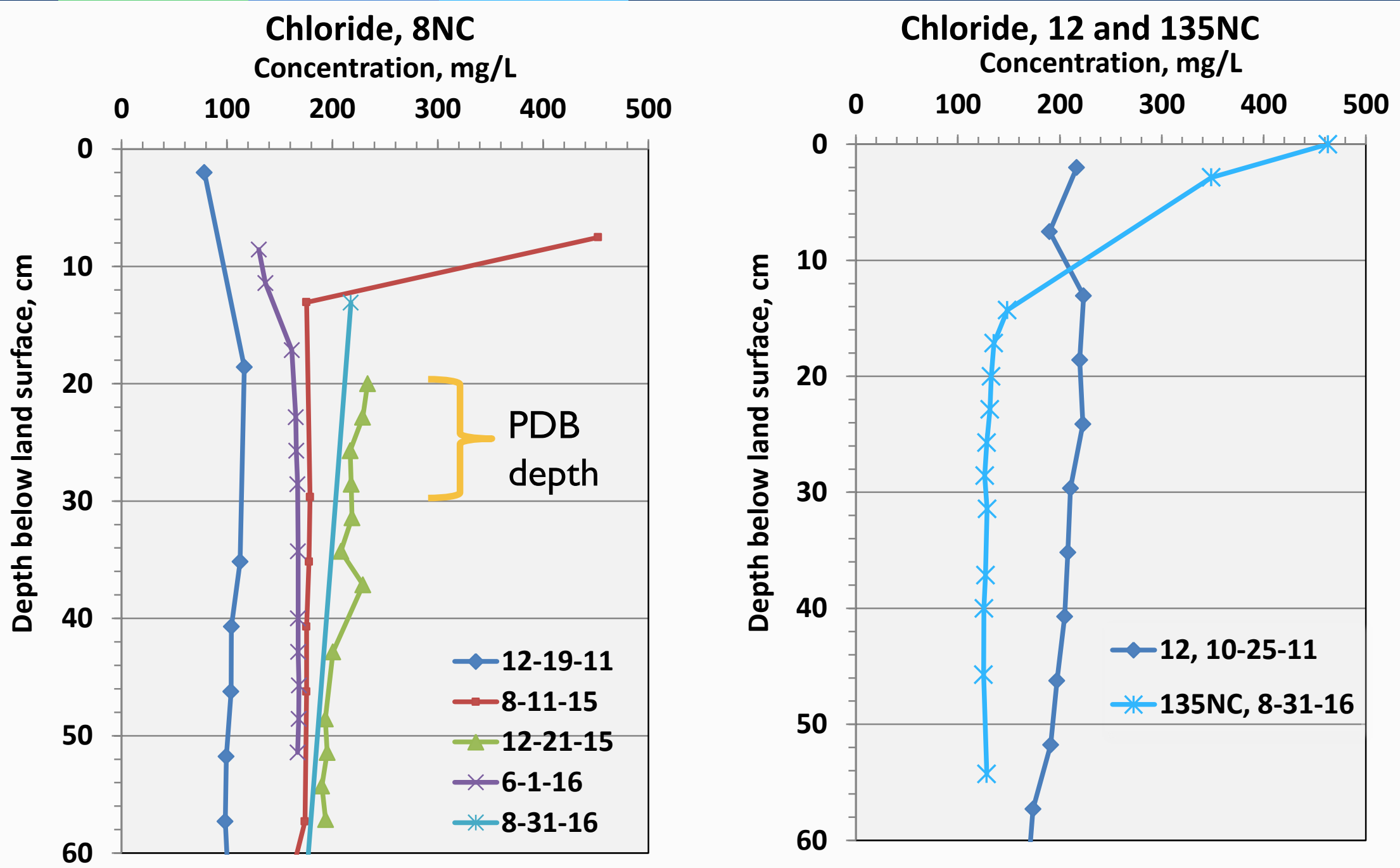


\section{VOC Composition with Depth (Peepers)- effect of surface-water infiltration or ET?}

\section{PDB depth}

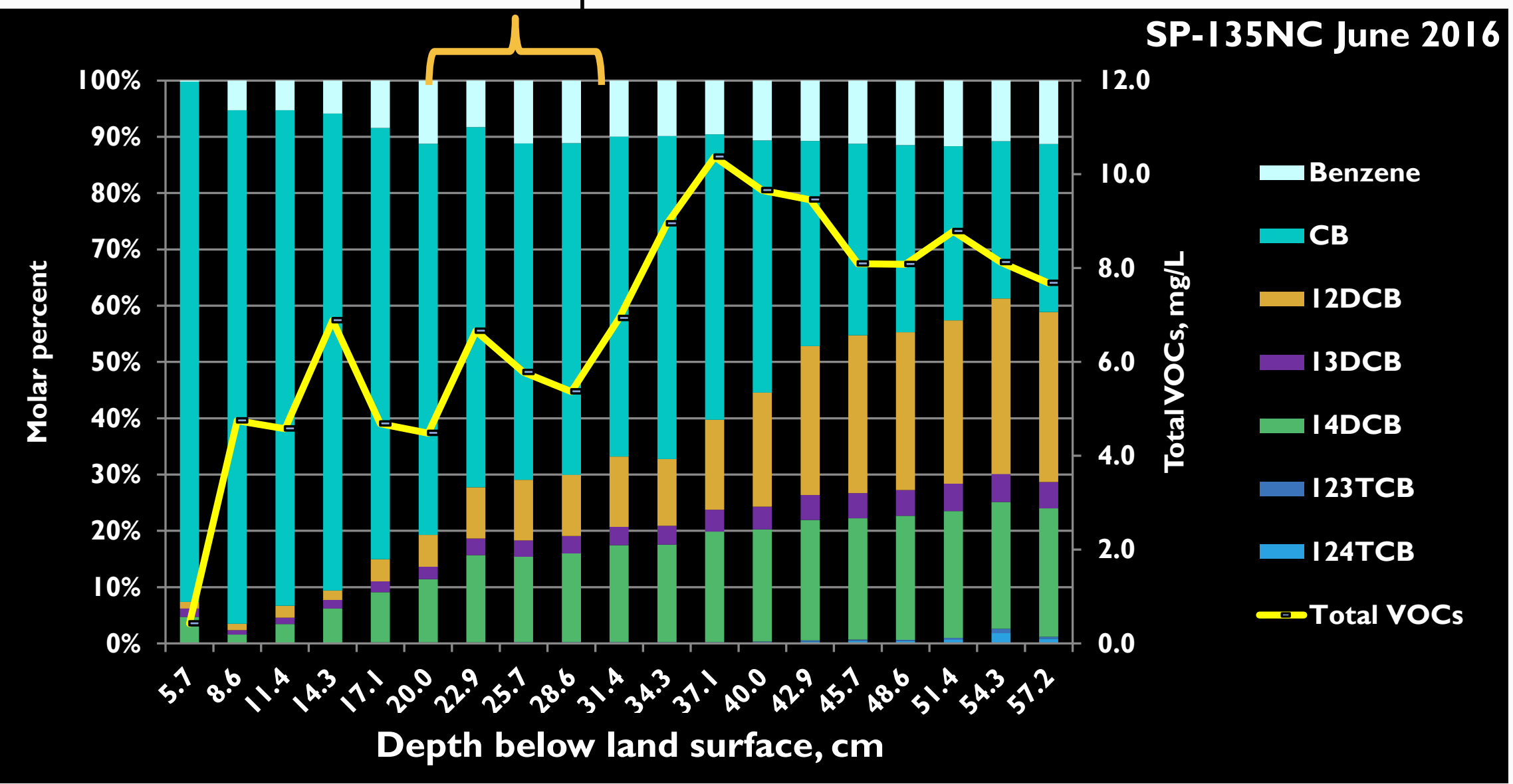

Limited evidence of dilution or ET effect- primarily top sampling depth). ET would preferentially strip lighter VOCs. 


\section{VOCs in Piezometers and PDBs, Aquifer to Shallow Wetland Groundwater}
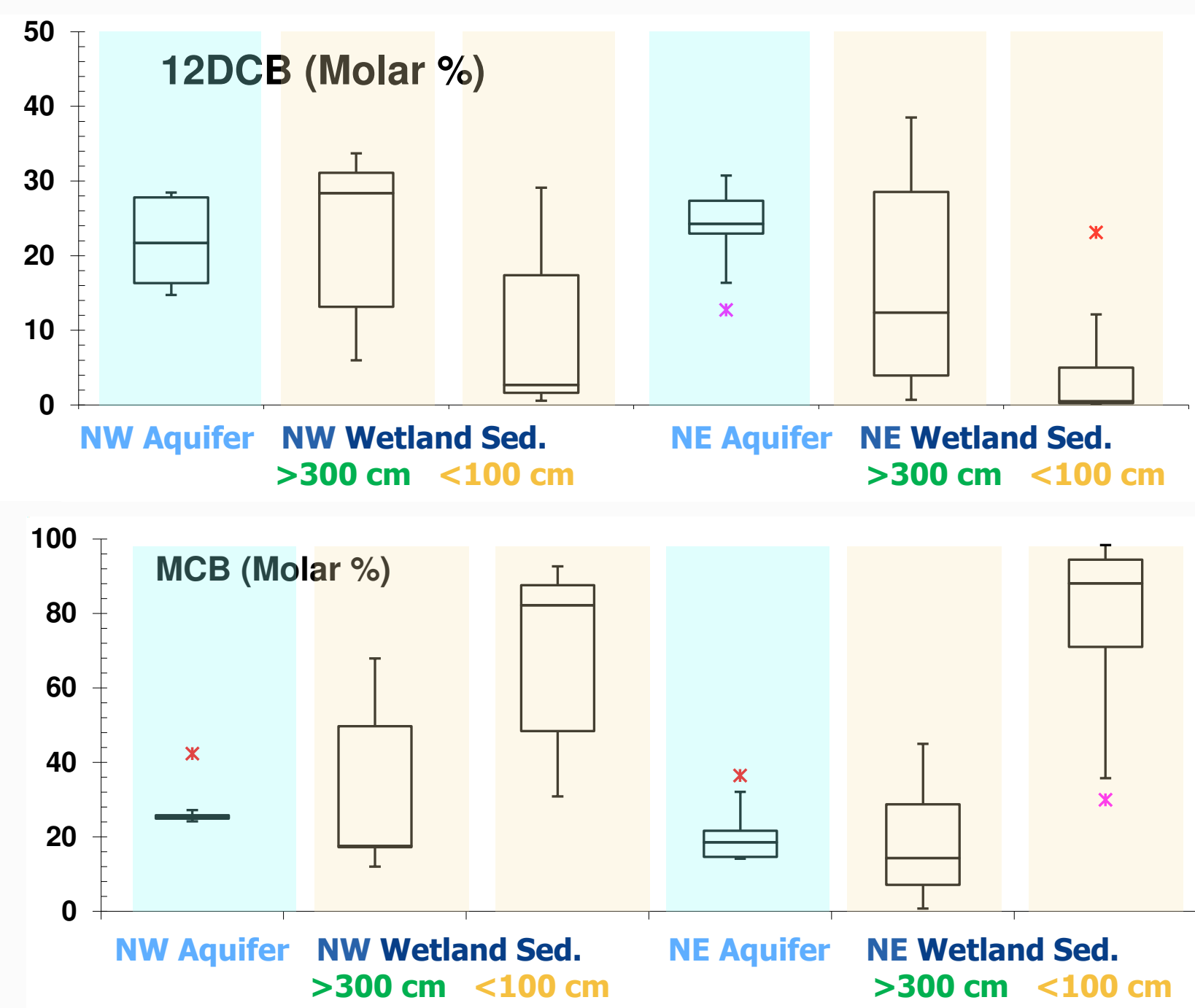

Greatest change occurs in the shallow wetland groundwater, not between aquifer and deep wetland groundwater.

A change in the contaminant source feeding into aquifer is not the cause of the observed VOC changes. 


\section{PDBs, Shallow Wetland Groundwater (30- $45 \mathrm{~cm}$ depth)}
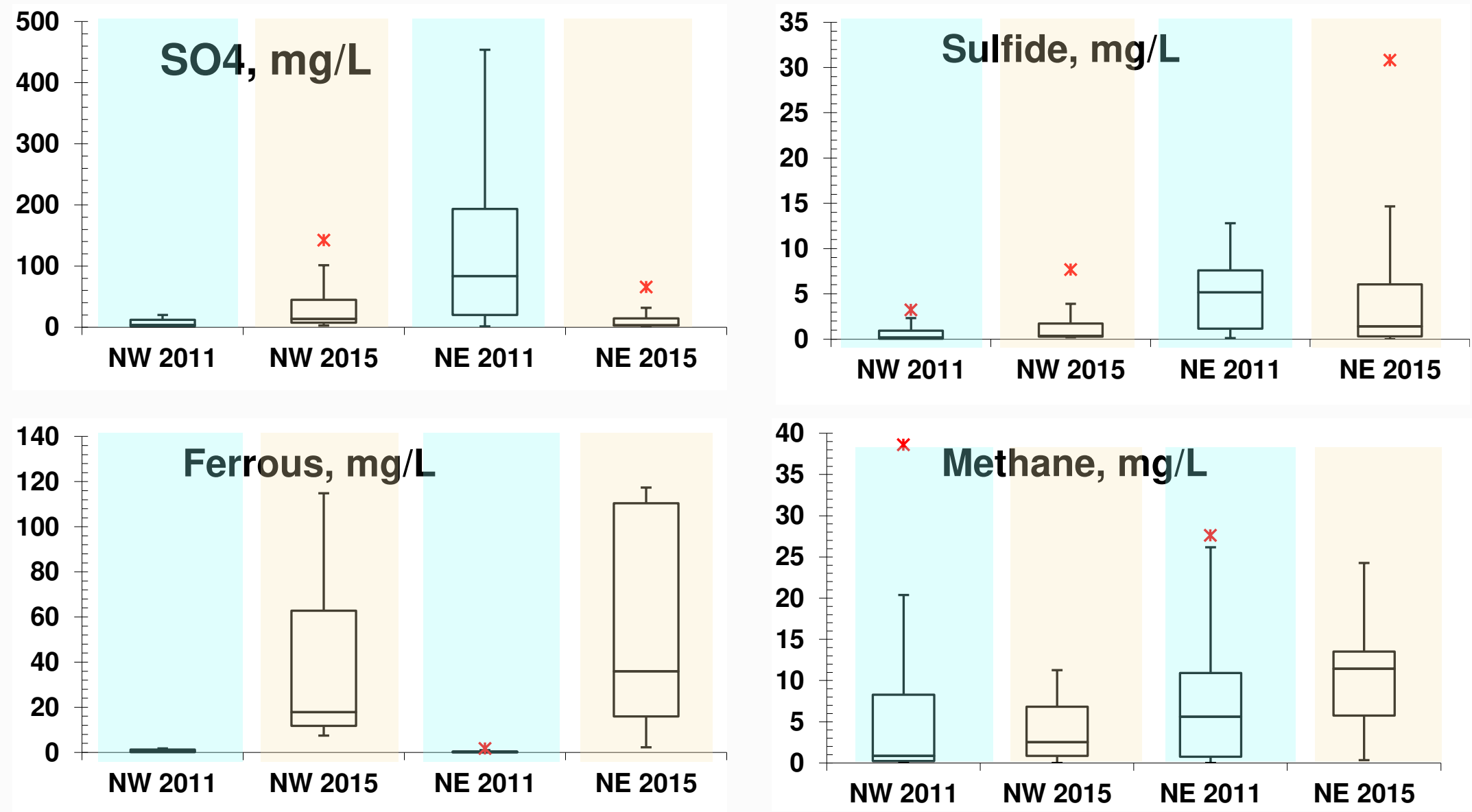

In 20I5, general decrease in sulfate and increase in reduced species compared to $201 \mathrm{I}$. 


\section{Reduced Species in Piezometers and PDBs, Aquifer to Shallow Wetland Groundwater}

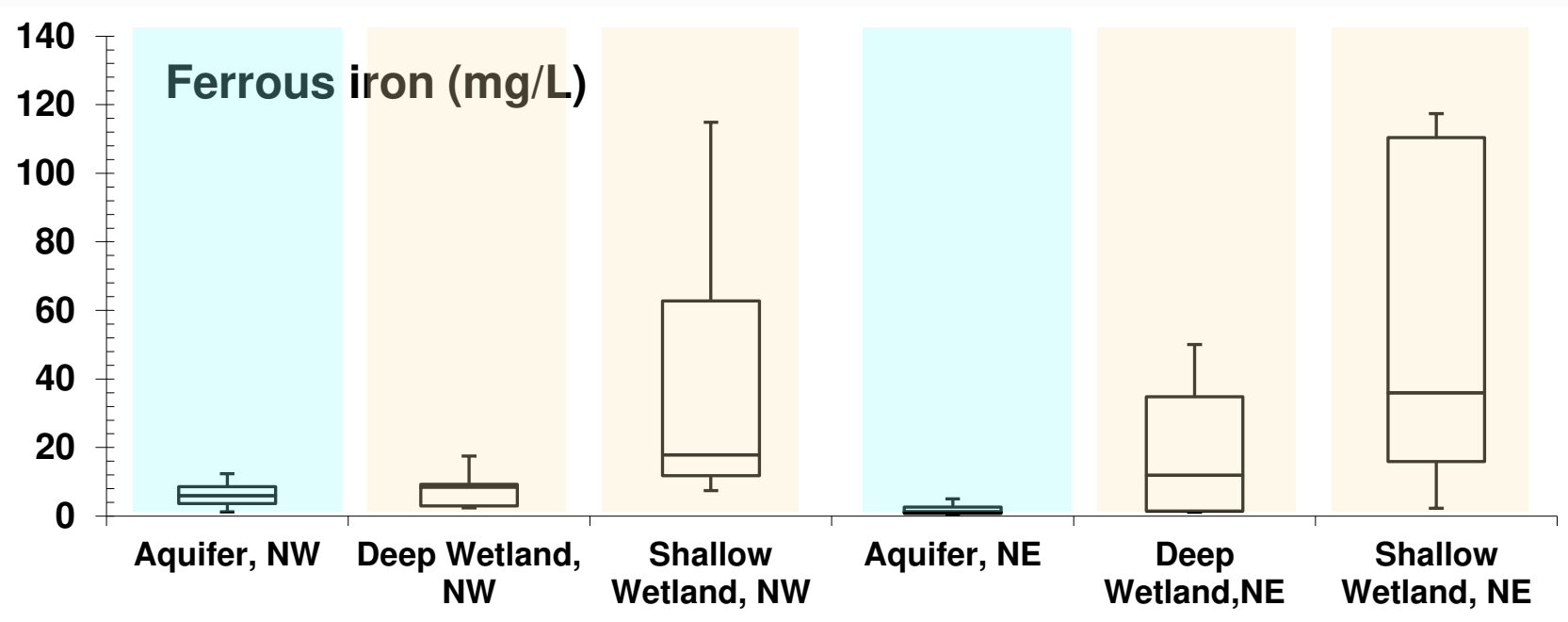

Iron, sulfide, and
methane primarily
about same in
aquifer and deep
wetland
groundwater.
As for VOCs,
change occurs
primarily in the
shallow wetland
groundwater.

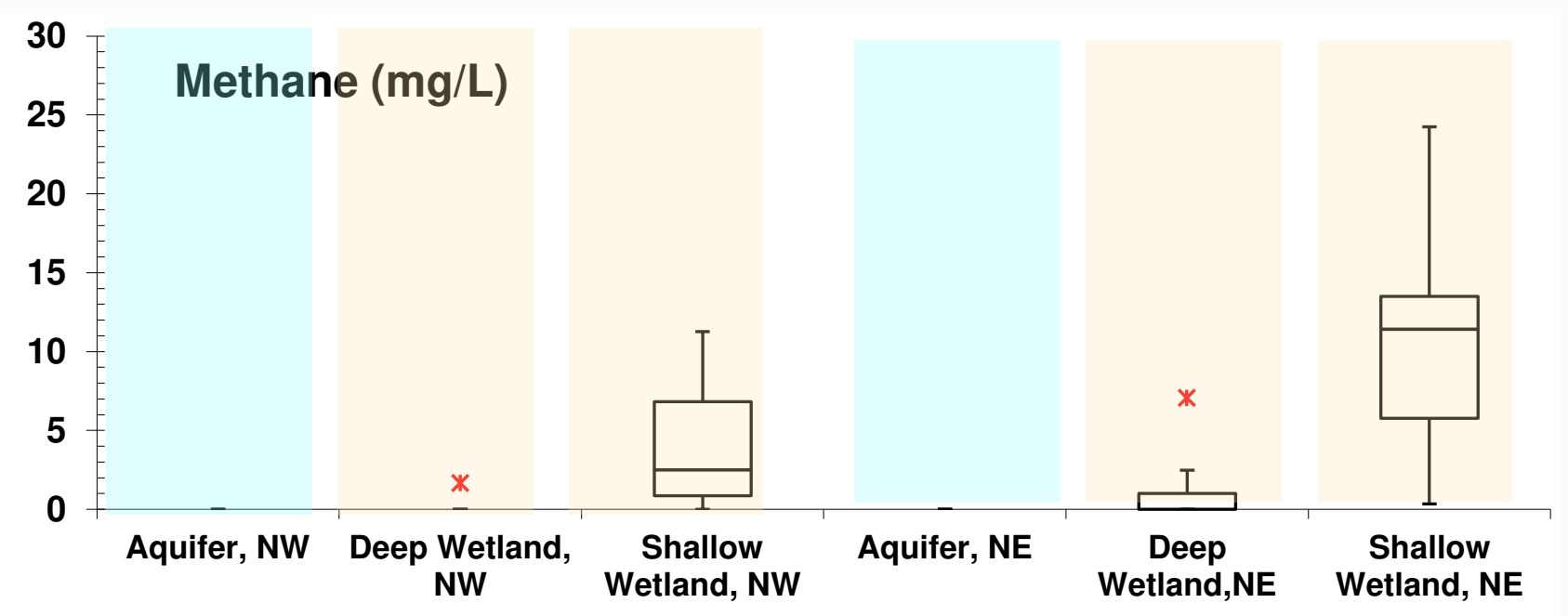




\section{Reduced Species with Depth, 2011 and 2015-16}
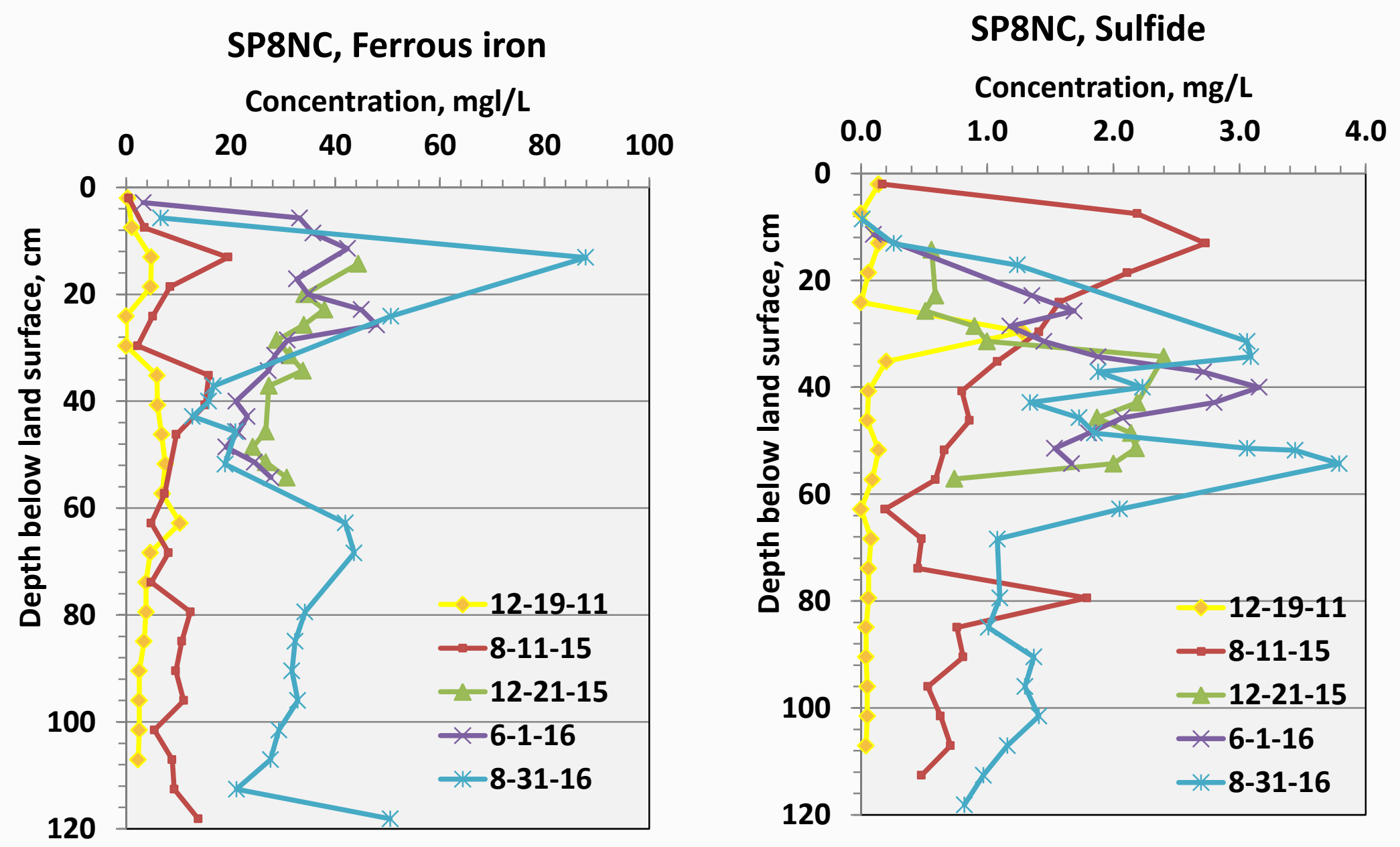


\section{Nitrate and Sulfate in Piezometers and PDBs, Aquifer to Shallow Wetland Groundwater}

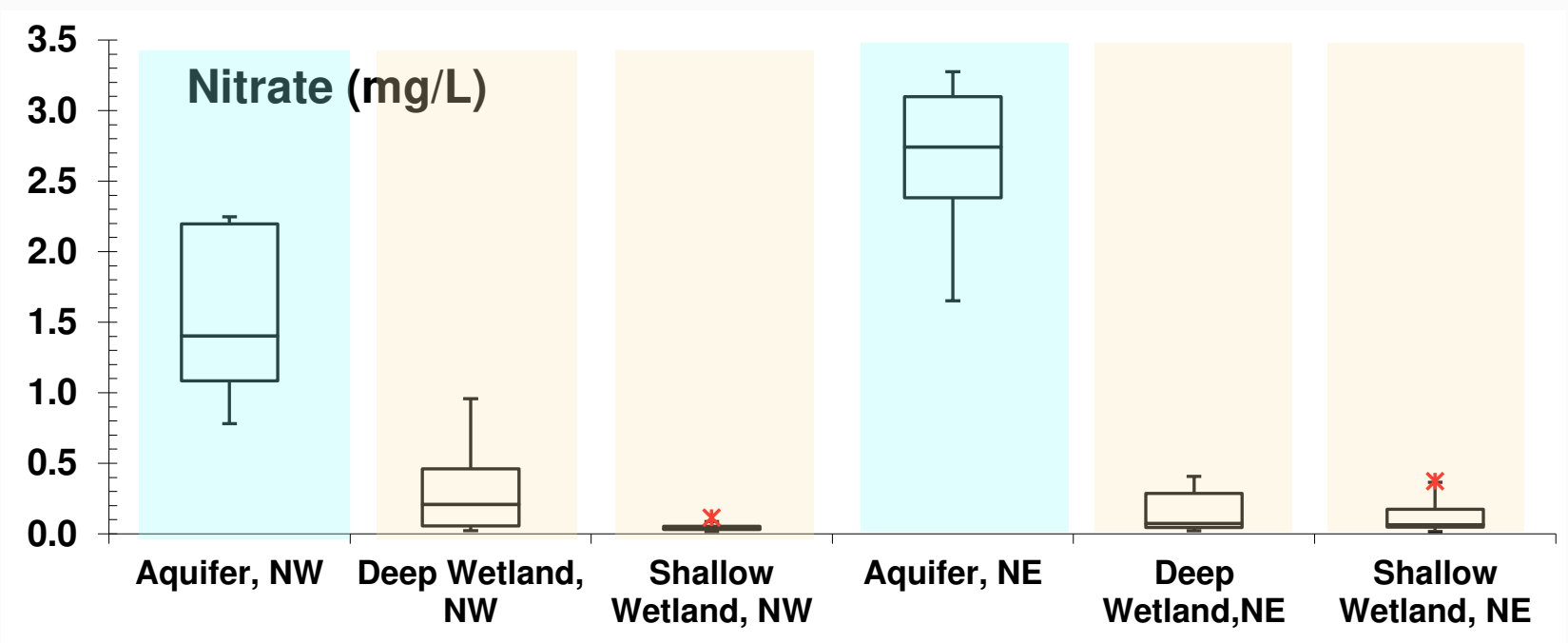

Terminal electron
acceptors
decreased between
aquifer and
between deep and
shallow wetland
groundwater.
However, marked
change in anaerobic
biodegradation of
chlorinated
benzenes observed
only with increase
in reduced species
in the shallow
groundwater.

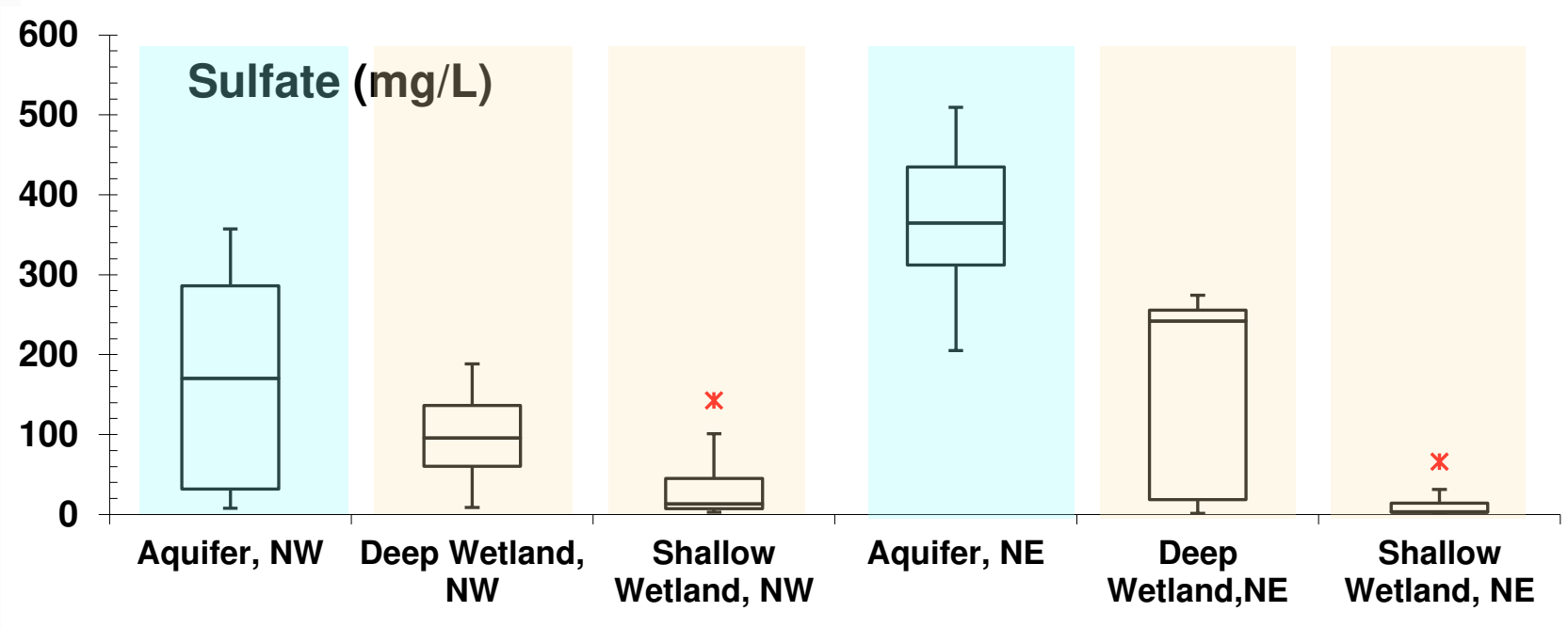




\section{DehaLococcoides Abundance in Shallow Wetland Sediment}

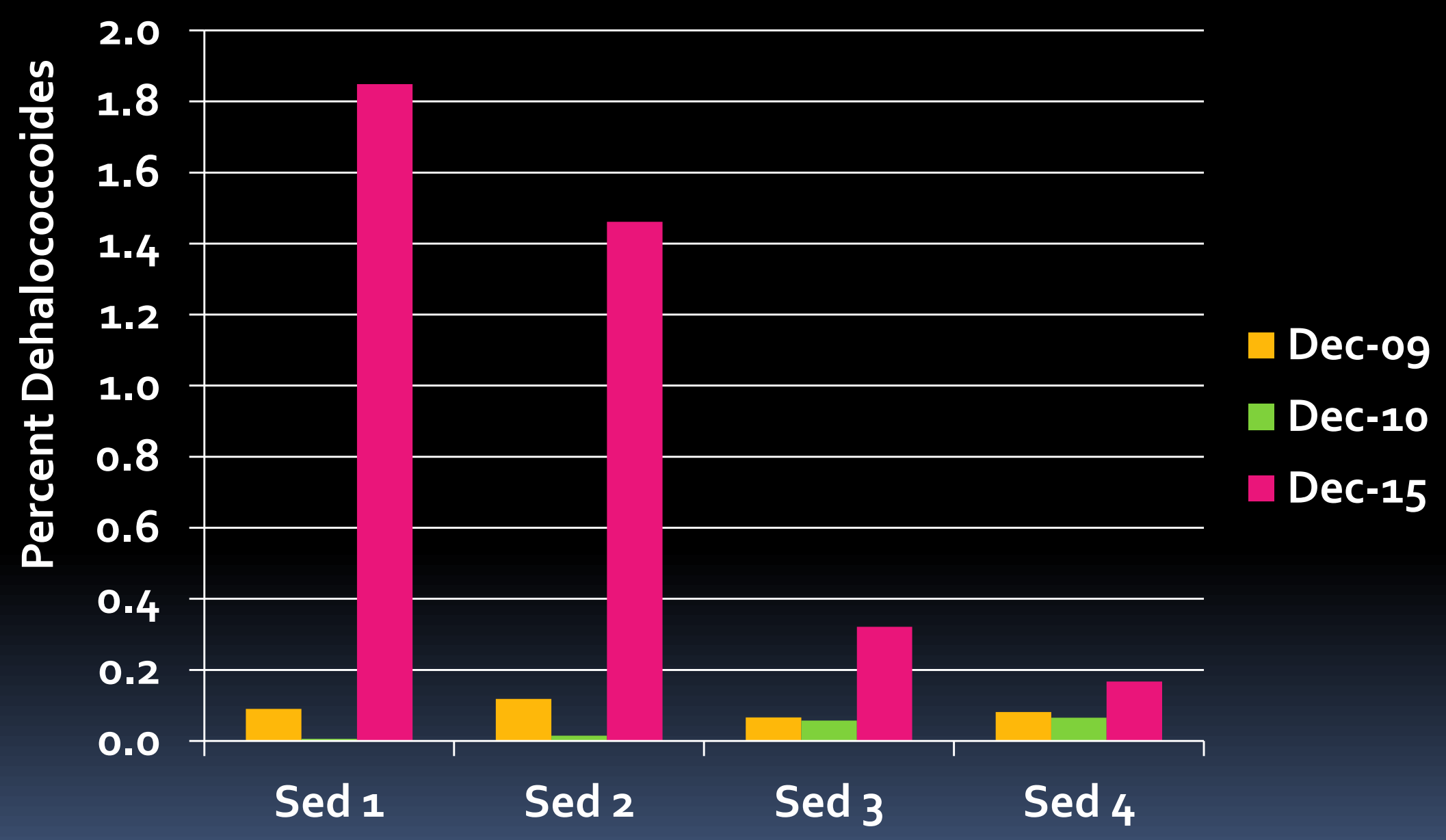




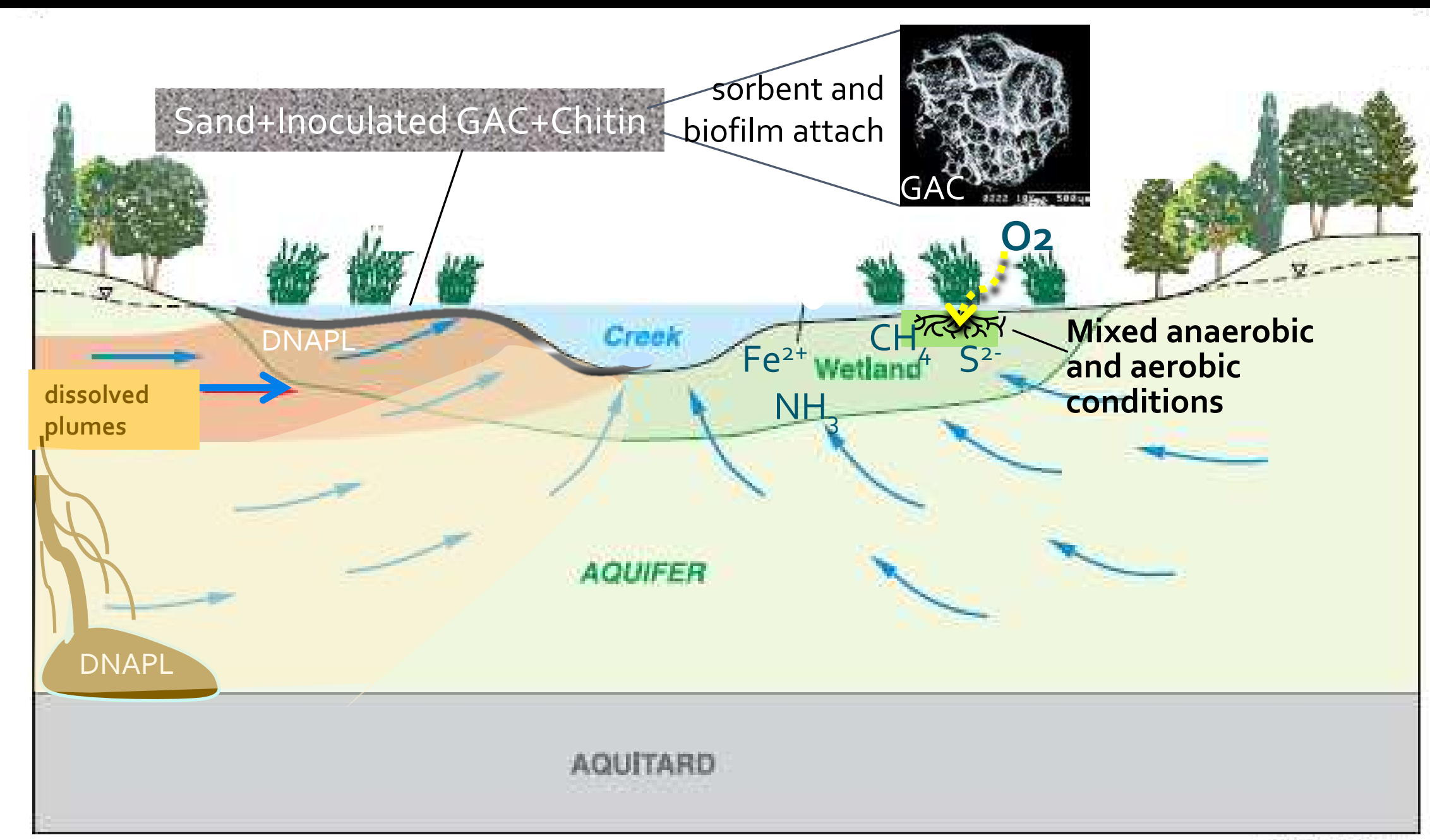

NOT TO SCML

Conceptual model for contamination and dual-biofilm GAC barrier Study funded by EPA, and NIEHS grant with co-PIs Dr. Bouwer (JHU) and Drs. Durant and Wadhawan (Geosyntec) 


\section{Reactive Barrier Concept}

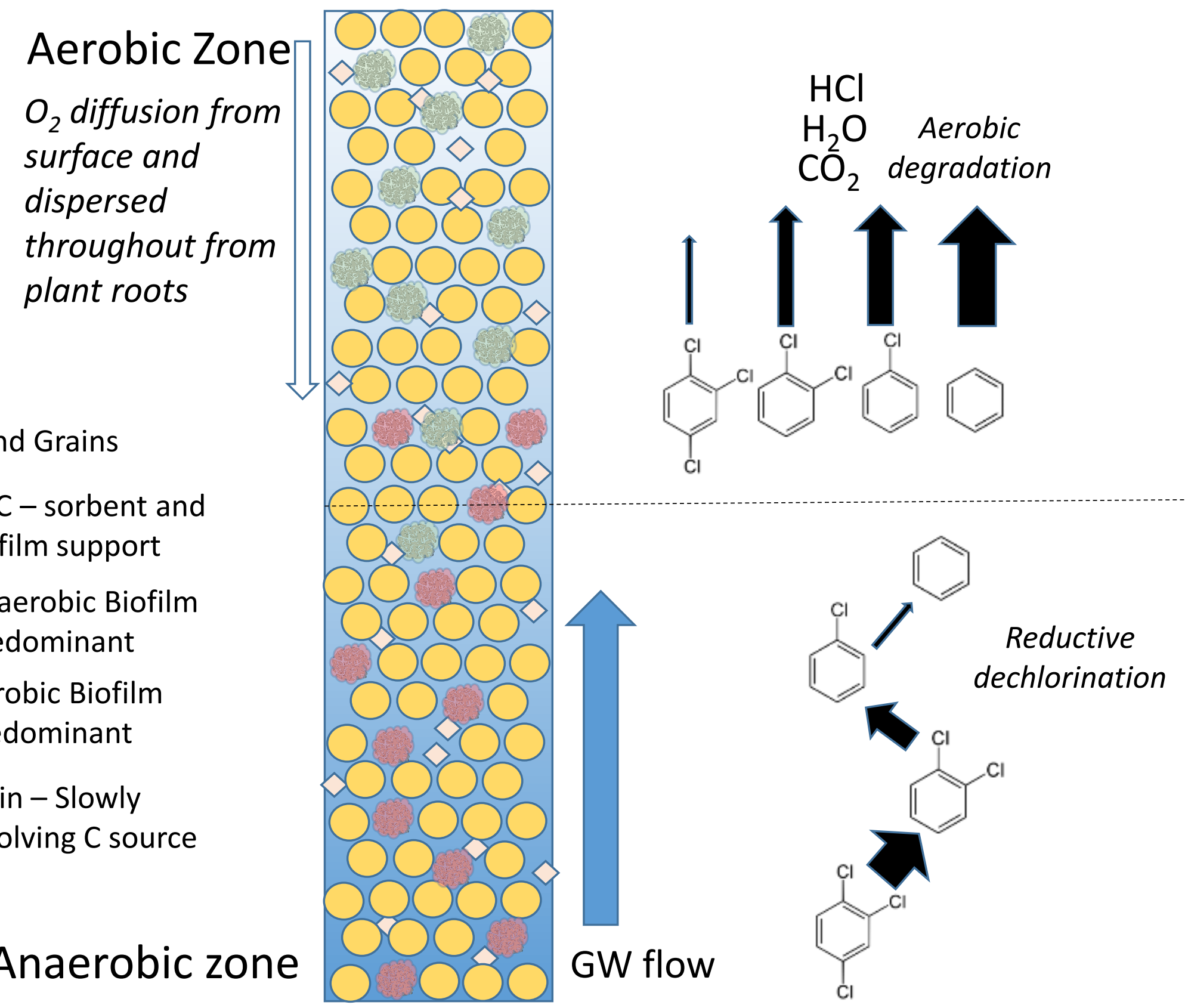




\section{Conclusions}

Site 13, view from site II, low tide,

May 2015. (Photo by Jessica Teunis, USGS.)

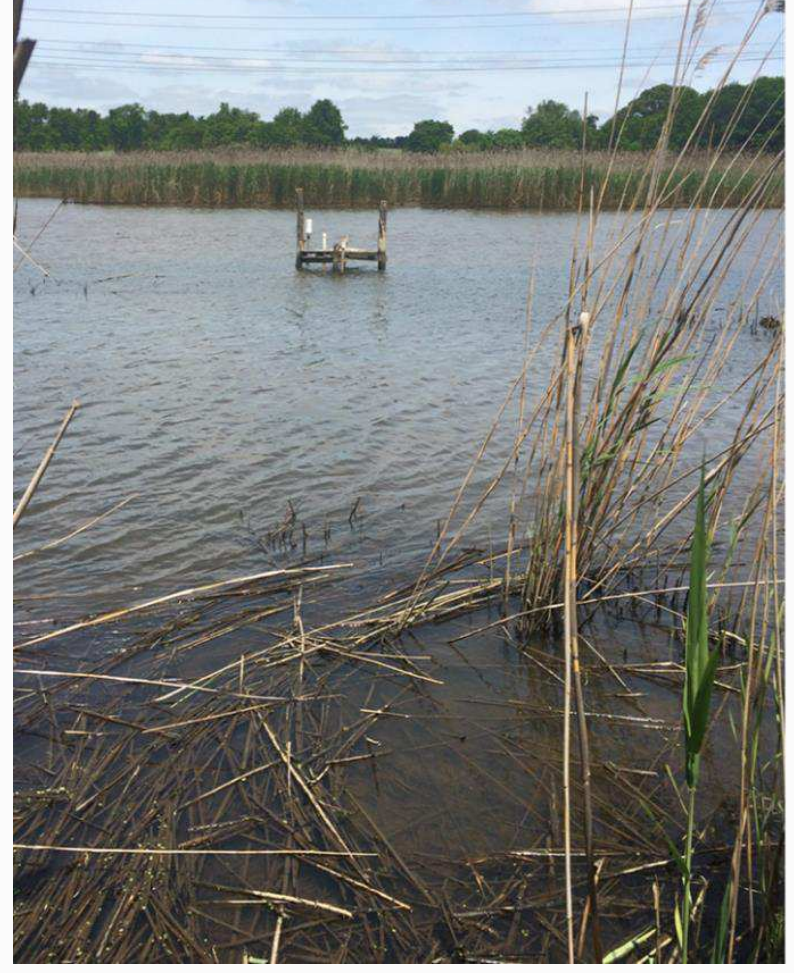

- Biogeochemistry changes and increase in Dhc population in wetland sediment in 2015 -16 compared to 2010-11 indicate reductive dechlorination became prominent.

- Rise in surface water elevation after broken tide gates was only change between 2010-11 and 2015 to account for these biogeochemical changes.

- Percent MCB, still a toxic compound, increased to over $80 \%$ of the VOC composition in 2015-16. Biodegradation needs to be complete to be a remedy.

- Increase in reducing conditions could make remedy that would combine anaerobic and aerobic chlorobenzene-degrading bacteria more difficult.

Biodegradation reactions are a major factor in fate, toxicity, and remediation of organic contaminants in many wetland environments. These processes could change significantly with increased extent and duration of flooding with sea level rise. 